\title{
Management of Irrigation Water and Organic Matter Application Contribution in Improving Some Soil Properties and Yields - Water Productivity of Sugar Beet and Cotton in Salt Affected Soil
}

\author{
Megahed M. Amer, E.A.E. Gazia, Hesham. M. Aboelsoud and S.H. Rashed \\ Soils Improvement and Conservation Dept., Soils, Water and Environ. Res. Instit. \\ (SWERI), Agric. Res. Center (ARC), Giza, Egypt
}

\begin{abstract}
$\mathbf{T}$ WO field trials were carried out at Sakha Agric. Res. Station Farm, Kafr El-Sheikh Gov., and Egypt during two successive growing seasons (2018/019 and 2019). The experiments were conducted in split-split plot design with three replicates. The aim of this study was to investigate the impact of irrigation water management and organic matter application as partial replacement of mineral fertilizers on some soil properties, yield, water productivity of sugar beet and cotton and economic returns in salt affected soil. The main investigated factors included irrigation treatments at 80,100 and $120 \%$, respectively from evaporation pan class A. The fertilization treatments included applying $\mathrm{N}$-fertilizer at three rates of 100,80 and $60 \% \mathrm{~N}$ from recommended dose in combination with compost (as 0, 20 and 40\%). Two levels of K-humate (12 and $24 \mathrm{~kg} \mathrm{ha}^{-1}$ ) were also applied. The results showed that cation exchange capacity, soil organic matter, infiltration rate and hydraulic conductivity were influenced by all treatments and their interactions. Productivity of water or irrigation water, economic yield and net return from water unit for sugar beet and cotton were recorded the highest values with $\mathrm{I}_{1} * \mathrm{~N}_{3} * \mathrm{H}_{2}$ interaction. Therefore, the irrigation and organic matter managements could be considered as a proper approach to sustain the soil and water resources in particular under salt affected soil.
\end{abstract}

Keywords: Cation exchange capacity, Cotton, economic returns, Hydraulic conductivity, Infiltration rate, Soil organic matter, Sugar beet, Water productivity

\section{Introduction}

Salt-affected soils occupy approximately $955 \mathrm{Mg}$ ha, $10 \%$ of total surface of dry lands, $20 \%$ of the irrigated lands in the world and 30\% in Egypt (Elbasiouny et al. 2017). In the clayey soil, the high content of clay particles probably affect soil properties directly or indirectly (Sarkar et al., 2018), causing soil compaction(Churchman, 2018) and probably rising many potential problems, e.g. low infiltration rates (Alaoui et al., 2018) beside of poor drainage and aeration conditions (Amer et al. 2018). Soil organic matter plays an important role in terrestrial and agricultural ecosystems. Nowadays, the intensive agriculture frequently results in a significant soil degradation and soil carbon depletion (Plaza-Bonilla et al. 2015). More recently, European policy in the agricultural sector has placed more emphasis on soil organic carbon, as an indicator for both soil quality and as a means to offset $\mathrm{CO}_{2}$ emissions through soil carbon sequestration (Lugato et al. 2014). Integrated nutrient management is a judicious use of organic and inorganic sources of nutrient to crop fields for sustaining and maintaining both of soil fertility and productivity (Wailare and Kesarwani, 2017). Ibrahim and Abd El-Hafeez (2017) indicated that soil properties and cotton yield were improved by application of $75 \%$ recommended of NPK and 5ton FYM/ fed. Khambalker et al (2017) stated that combined organic manure with inorganic fertilizers enhanced cotton yield and its components better than inorganic fertilizer alone. Yield, water and $\mathrm{N}$ relationships or production functions are useful tools in the management of water and optimized $\mathrm{N}$ application for maximization of crop productivity. These functions can be used in managing water resource for achieving maximum returns with minimum amount of irrigation water (English and Raja, 1996). Aiad (2019) found that the highest values of economic efficiency

Corresponding author: megahedamer3@gmail.com 
and net return from water unit were achieved with 5-ton compost fed $^{-1}$ under 55\% depletion of available soil moisture for wheat and maize. Also, they found that soil basic infiltration rate was increased with soil amendments. Yang et al. (2016) showed that application of organic manure significantly increased $\mathrm{N}$ accumulation rate greater than with mineral fertilizer. Chaney and Swift (1986) stated that humic substances were capable of aggregates stabilization for a long term in which they are mainly involved in the microaggregate formation. Amer et al (2019) found that application of compost improved soil physical properties such as its total porosity. Ladislav et al. (2018) concluded that amending of soil by organic fertilizers helps to achieve the long-term stable yields and maintain optimal soil properties. Awwad et al. (2015) concluded that application of $15 \mathrm{~kg}$ potassium humate $\mathrm{fed}^{-1}$ and irrigation at $100 \%$ of field capacity resulted in the highest yield and yield attributes, water use efficiency and some soil properties. Leaching requirement must be applied to reduce salt build-up in the root zone (Ayars et al., 1993). Meleha (2000) reported that water requirements for cotton plants were ranged between 3500 and $3638\left(\mathrm{~m}^{3} \mathrm{fed}^{-1}\right)$ and many studies were carried out to improve irrigation productivity to achieve the proper economic use of water. Getinet (2016) concluded that nutrients are slowly released from organic compost and not directly absorb by the plants. Therefore, plants are unable to access required amount of nutrients in the critical yield-forming period. Hence, combining application of compost with an application of inorganic fertilizer is a good strategy for increasing crop productivity, reducing the cost of inorganic fertilizer and improving soil properties. Yonts (2011) observed that root and sugar yield of sugar beet was the highest with full irrigation, while sugar content did not significantly change by reducing irrigation water by $25 \%$. Kiziloglu et al. (2006) indicated that the deficit irrigation significantly decreased root, leaf, and total sugar yield of sugar beet under semiarid and cold season climatic conditions. Topak et al. (2011) found that root and sugar yields of sugar beet significantly decreased by the increasing water deficit in the semiarid region. Therefore, the management of irrigation and fertilization practices was and still one of the most important issues for the sustainable agriculture in particular under salt-affected soils. So, this investigation was carried out to study the effect of irrigation management and organic-fertilization as partial replacement instead of mineral fertilization on some soil properties and yield-water productivity of sugar beet and cotton in salt affected soil. In addition, economic evaluation was considered.

\section{Materials and Methods}

Field trials were carried out at Sakha Agric. Res. Station Farm, Kafr El-Sheikh Gov., Egypt (31 ${ }^{\circ}$ $05 \mathrm{~N}$ latitude and $30^{\circ} 57 \mathrm{E}$ longitude) with sugar beet (2018/2019 winter season) and cotton Giza 94 (2019 summer season) under salt-affected soil conditions The meteorological data from Sakha Station during the growing seasons are presented in Table (1). The experiments were conducted in split-split plot design with three replications; the main plots were assigned to irrigation, i.e., at 80 $\left(\mathrm{I}_{1}\right), 100\left(\mathrm{I}_{2}\right)$ and $120 \%\left(\mathrm{I}_{3}\right)$ of evaporation pan class A. A check book is used to schedule irrigations. The value for daily water use or for few days is subtracted from the stored soil water is exhausted, it is the time to irrigate. The irrigation water depths applied were $82.0 \mathrm{~mm}(80 \% \times 102.3 \mathrm{~mm})$ with $\mathrm{I}_{1}, 102.3 \mathrm{~mm}(100 \% \times 102.3 \mathrm{~mm})$ with $\mathrm{I}_{2}$ and $123.0 \mathrm{~mm}(120 \% \times 102.3 \mathrm{~mm})$ with $\mathrm{I}_{3}$, according to $60 \%$ soil moisture depletion of available water had evaporated from pan evaporation.

Taking pan coefficient into consideration, crop coefficients of sugar beet and cotton for different growth stages were taken from FAO paper No. 56 (Richard et al. (1977). The inflow rate was measured with a rectangular sharp crested weir using the equation described by Masoud (1969) as follow:

$$
\mathrm{Q}=\mathrm{CLH}^{3 / 2}
$$

Where, Q: discharge $\left(\mathrm{m}^{3} \mathrm{sec}^{-1}\right)$, L: length of the crest in meters, $\mathrm{H}$ : crest head in meters, $\mathrm{C}$ : empirical coefficient.

Subplots were devoted to three $\mathrm{N}$-fertilizer treatments using different ratios from $\mathrm{N}$-mineral and N-organic from the N-recommended. The $\mathrm{N}$ treatments were $100 \%$ mineral-N $\left(\mathrm{N}_{1}\right), 80 \%$ mineral- $\mathrm{N}+20 \%$ compost- $\mathrm{N} \quad\left(\mathrm{N}_{2}\right)$ and $60 \%$ $\mathrm{N}$-mineral $+40 \%$ N-compost $\left(\mathrm{N}_{3}\right)$. The sub-sub plot included two levels of potassium humate (12 and $\left.24 \mathrm{kgha}^{-1}\right)$. The recommended of mineral-N rates (192 and $\left.180 \mathrm{kgha}^{-1}\right)$ were added in the form of urea $(46.5 \% \mathrm{~N})$ and ammonium nitrate $(33 \% \mathrm{~N})$ for sugar beet and cotton, respectively. The pervious cultivated crop before sugar beet was rice. The plot area was $150 \mathrm{~m}^{2}(5 \times 30 \mathrm{~m})$. The required compost rates were mixed with the upper soil layer before planting of sugar beet (2.6 
and $\left.5.2 \mathrm{Mg} \mathrm{ha}^{-1}\right)$ and cotton $(2.8$ and $5.5 \mathrm{Mg}$ $\mathrm{ha}^{-1}$ ) for 20 and $40 \%$ from the recommended $\mathrm{N}$, respectively. The chemical composition of compost in $\mathrm{mg} \mathrm{kg}^{-1}$ were $1.4 \mathrm{~N}, 0.68 \mathrm{P}, 2.10 \mathrm{~K}$ and $38.9 \mathrm{OM}$ with $\mathrm{C} / \mathrm{N}$ ratio of $18: 1, \mathrm{pH} 7.61$, EC $2.91 \mathrm{dSm}^{-1}$ and moisture content of $28.15 \%$. The chemical compositions of K-humate in $\mathrm{mg}$ $\mathrm{kg}^{-1}$ were 75 humic acid, $10 \mathrm{~K}_{2} \mathrm{O}, 4$ fluvic and 2 iron, $\mathrm{pH}$ 6.70. Soil samples were collected for all treatments from $0-20,20-40$ and $40-$ $60 \mathrm{~cm}$ layers before experiments and after harvesting of both crops to carry out physical and chemical analysis. Cation exchange capacity (CEC) was determined according to Richard (1954). OM content was determined using the Walkley and Black method (Page et al., 1982), infiltration rate was determined using double cylinder infiltrometer (Garcia, 1978), hydraulic conductivity was measurements by auger hole method (Van Beers, 1958) as shown in Table (2). Sugar beet (Beta vulgaris L.) was sown in $1^{\text {th }}$ Sept., 2018 and harvested in $25^{\text {th }}$ Feb, 2019, while cotton (Gossypium spp), variety Giza 94 was sown in $10^{\text {th }}$ April, 2019 and harvested on $30^{\text {th }}$ Sept., 2019. Cotton and sugar beet yields $\left(\mathrm{Mg} \mathrm{ha}^{-1}\right)$ were recorded for each treatment. The sugar content of sugar beet was measured by the Factory of Sugar, El-Hamoul, Kafr El-Sheikh.

Amount of water applied $\left(\mathrm{m}^{3} \mathrm{ha}^{-1}\right)$ : was determined from the orifice equation as described by Brater and King, 1976 as follow:

$$
\mathrm{Q}=\mathrm{CA}(2 \mathrm{GY})^{1 / 2}
$$

Where: Q: discharge rate $\left(\mathrm{m}^{3} \mathrm{sce}^{-1}\right)$, C: discharge coefficient ranges from 0.6 to $0.8, \mathrm{~A}$ : area of orifice $\left(\mathrm{m}^{2}\right)$, G: accelerating of gravity $\left(9.8 \mathrm{~m} \mathrm{sec}^{-2}\right)$, Y: the head over the center of orifice causing free flow. Water consumptive use (CU)

Soil moisture percentage was determined (on weight basis) before and 48 hours after each irrigation as well as at harvest. The soil samples were taken from successive layer in the effective root zone $(0-20,20-40$ and $40-60 \mathrm{~cm})$. This method of consumed water is depending upon soil moisture depletion or so-called actual cropwater consumed (ETc); the amount of $\mathrm{Cu}$ was calculated in the effective root zone of $60 \mathrm{~cm}$ as reported by Hansen et al (1979).

$$
C U=\sum_{i=i}^{i=N} \frac{\theta 2-\theta 1}{100} * D b i * D i
$$

TABLE 1. Climatological data, potential evapotranspiration $\left(\mathrm{ET}_{0}\right)$ and maximum evapotranspiration (ET $_{\mathrm{m}}$ for

\begin{tabular}{|c|c|c|c|c|c|c|c|c|c|c|c|}
\hline \multirow[b]{2}{*}{ Month } & \multirow[b]{2}{*}{ T. $\left(C^{\circ}\right)$} & \multirow[b]{2}{*}{$\begin{array}{l}\text { R.H. } \\
\text { (\%) }\end{array}$} & \multirow[b]{2}{*}{$\begin{array}{c}\text { W.V. } \\
(\mathrm{km} \\
\left.\text { day }^{-1}\right)\end{array}$} & \multirow[b]{2}{*}{$\begin{array}{c}\text { period } \\
\text { day }\end{array}$} & \multicolumn{2}{|c|}{ P.E. } & \multirow[b]{2}{*}{ K pain } & \multirow[b]{2}{*}{$\mathbf{E T}_{0}$} & \multirow[b]{2}{*}{$\mathbf{K}_{\mathrm{c}}$} & \multicolumn{2}{|c|}{$\mathbf{E T}_{\mathrm{m}}$} \\
\hline & & & & & 䒿 & 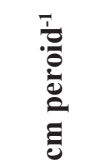 & & & & cm & $\mathbf{m}^{2}$ \\
\hline \multicolumn{12}{|c|}{ Sugar beet $(2018 / 2019)$} \\
\hline Sept. & 28.2 & 65.7 & 68.7 & 30 & 0.498 & 14.94 & 0.8 & 11.95 & 0.5 & 5.98 & 602.38 \\
\hline Oct. & 25.1 & 66.1 & 57.9 & 30 & 0.324 & 9.720 & 0.8 & 7.78 & 0.9 & 7.00 & 705.44 \\
\hline Nov. & 21.2 & 70.6 & 24.2 & 30 & 0.16 & 4.800 & 0.8 & 3.84 & 1.2 & 4.61 & 464.49 \\
\hline Dec. & 16.7 & 67.8 & 33.1 & 31 & 0.108 & 3.348 & 0.8 & 2.68 & 1.2 & 3.21 & 323.98 \\
\hline Jan. & 15.6 & 72.6 & 28.6 & 31 & 0.114 & 3.534 & 0.8 & 2.83 & 1.2 & 3.39 & 341.98 \\
\hline \multicolumn{12}{|c|}{ Cotton (2019) } \\
\hline Apr. & 23.2 & 57.20 & 68.4 & 20 & 0.413 & 8.260 & 0.8 & 6.61 & 0.4 & 2.64 & 266.43 \\
\hline May. & 28.7 & 65.75 & 103.5 & 30 & 0.683 & 20.490 & 0.8 & 16.39 & 0.7 & 11.47 & 1156.62 \\
\hline Jun. & 30.5 & 69.80 & 83.8 & 31 & 0.846 & 26.226 & 0.8 & 20.98 & 1.15 & 24.13 & 2432.09 \\
\hline july & 31.0 & 70.65 & 68.7 & 30 & 0.808 & 24.240 & 0.8 & 19.39 & 1.15 & 22.30 & 2247.92 \\
\hline Agus. & 31.6 & 68.15 & 76.9 & 31 & 0.683 & 21.173 & 0.8 & 16.94 & 1.15 & 19.48 & 1963.50 \\
\hline Sept. & 30.2 & 57.20 & 68.4 & 30 & 0.59 & 17.700 & 0.8 & 14.16 & 0.6 & 8.50 & 856.40 \\
\hline
\end{tabular}
sugar beet and cotton

* T. $\left(\mathrm{C}^{\circ}\right)$, average of maximum and minimum temperature; R.H.: relative humidity; W.V.: wind velocity (at $2 \mathrm{~m}$ height); P.E.: Pan Evaporation. $\mathrm{K}$ pain, coefficient of evapotranspiration, $\mathrm{ET}_{0}$, potential evapotranspiration, $\mathrm{K}_{\mathrm{c}}, \mathrm{ET}_{\mathrm{m}}$, maximum evapotranspiration $\left(\mathrm{m}^{2} \mathrm{ha} \mathrm{i}^{-1}\right)$, Effective rainfall $(\mathrm{ER})=$ incident rainfall $\times 0.7$ (Novica, 1979$)$, rain effective $\left(161 \mathrm{~m}^{3}\right)$. Source: Meteorological station at Sakha Agric. Res. Station. 
where

$\mathrm{CU}=$ water consumptive use $(\mathrm{cm})$ in the effective root zone $(60 \mathrm{~cm})$

$\theta_{2=}$ soil moisture percentage 48 hours after irrigation

$\theta_{1=}$ soil moisture percentage before the next irrigation

Dbi= Bulk density of the specific layer $\left(\mathrm{Mg} \mathrm{m}^{-3}\right)$

$\mathrm{Di}=$ soil layer depth $(20 \mathrm{~cm})$.

$$
\begin{aligned}
& \mathrm{WP}=\frac{\text { Yield }\left(\mathrm{Kg} \mathrm{ha}^{-1}\right)}{\text { Water consumptive use }\left(\mathrm{m}^{3} \mathrm{ha}^{-1}\right)} \\
& \mathrm{PIW}=\frac{\text { Yield }\left(\mathrm{Kg} \mathrm{ha} \mathrm{Ka}^{-1}\right)}{\text { Water applied }\left(\mathrm{m}^{3} \mathrm{ha}^{-1}\right)}
\end{aligned}
$$

- Water productivity (WP) and irrigation water productivity (PIW): calculated by the following equations according to Ali et al. (2007) as follows:

\section{Economic evaluation}

Cash inflow and outflows for various treatments as of the local market price were calculated, and some economic indicators were also estimated such as: 1-Net return, which calculated by deducting the total cost from the total return (LE ha $\left.{ }^{-1}\right), 2$ - Benefit Cost Ratio (BCR) calculated by dividing the total seasonal return by total seasonal cost 3- Net return from water unit, calculated by dividing the net seasonal return by water applied (Gittinger, 1982). The data were analyzed statistically by analysis of variance (ANOVA) using M-State program according to Gomez and Gomez (1984). Treatment means were compared by Duncan's Multiple Range Test at 5\% level of significance (Duncan, 1955).

\section{Results and Discussion}

Soil Cation Exchange Capacity and Organic Matter

The effects of irrigation treatments, integrated mineral-N, organic-N and K-humate and their interactions on soil properties are given in Fig.1 and 2. The obtained data clearly revealed that C.E.C and SOM were responded to irrigation treatments, compost and K-humate applications as well as the interaction (Fig. 1). The interaction between $\mathrm{I}_{1} * \mathrm{~N}_{3} * \mathrm{H}_{2}$ recorded the highest values of CEC and SOM while they weren't affected by the individual mineral-N. The highest mean relative change of CEC and SOM for both seasons ( 40.3 and $12.7 \%$, respectively) were achieved with $\mathrm{I}_{1} * \mathrm{~N}_{3} * \mathrm{H}_{2}$ over that before treatments. The positive effect of compost on increasing CEC and SOM is mostly due to its high organic carbon and total $\mathrm{N}, \mathrm{P}$ and $\mathrm{K}$ contents. These results were supported by Ladislav et al. (2018) and Amer et al (2019)

Soil basic infiltration rate, IR and hydraulic conductivity $(K)$

The data show the IR and $K$ as affected by different treatments. The highest values of IR and $\mathrm{K}$ were obtained with the combination between $\mathrm{I}_{1}, \mathrm{~N}_{3}$ and $\mathrm{H}_{2}$ treatments. These results may be due the low density, highly porous structure and grain sized distribution of organic materials, so it rearranges the inter-aggregate pore spaces and consequently improves soil physical properties, e.g. soil bulk density, total porosity and aggregates stability. Moreover, it minimizes the potentiality of clayey soils towards degradation. These results supported by Awwad et al. (2015), Churchman (2018) and Amer et al. (2019).

TABLE 2: Some physical and chemical properties of the experimental soil

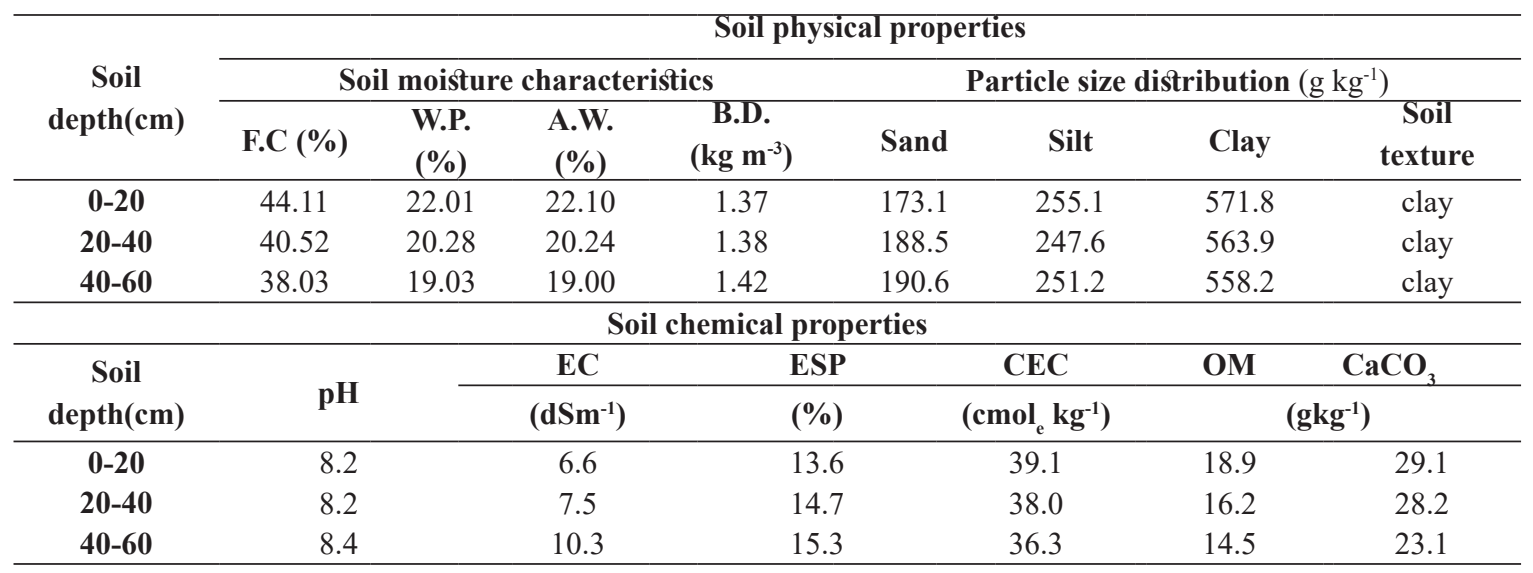

F.C.: Field Capacity; W.P.: Wilting Point; A.W.: Available Water; B.D.: Bulk Density; pH: was determined in soil water suspension (1:2.5); EC: was determined in saturated soil paste extract; ESP: Exchangeable Sodium Percent; CEC: Cation Exchange Capacity; OM: Organic Matter; N, P, K: available nitrogen, phosphorus and potassium according to Natural Resources Conservation Service (NRCS), Oregon State University, USA, the soil of experiment can be classified as saline soil (Horneck et al. 2007). 

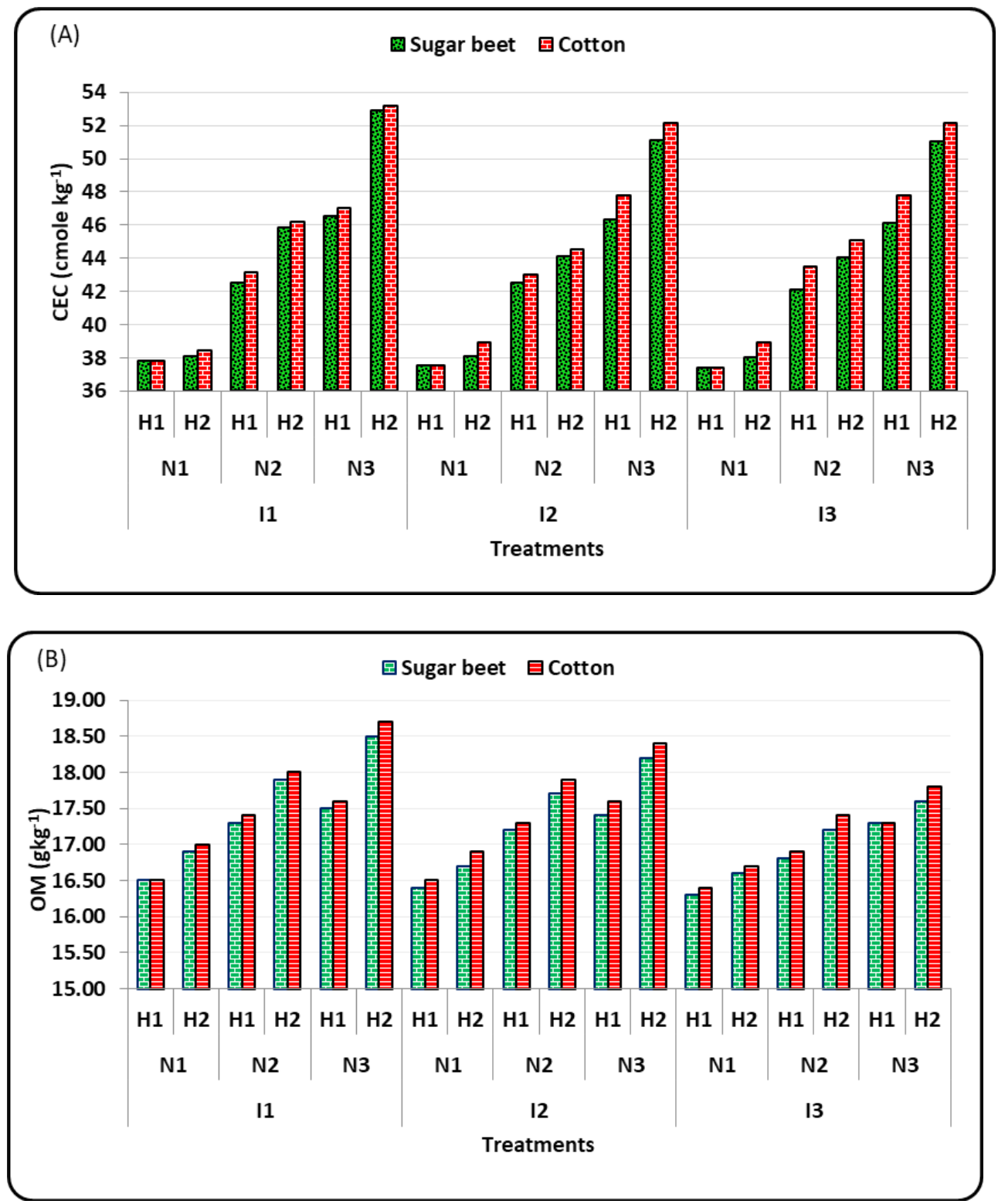

Fig. 1. Cation exchange capacity (A) and organic matter (B) as affected by irrigation treatments and organicchemical fertilizers

\section{Yield of sugar beet and cotton}

Crop productivity under salt-affected soils suffers from many problems related to the hazardous effects of salinity and sodicity. Table 3 shows the response of sugar beet and cotton yields to different irrigation and fertilization treatments and their interactions during the two growing seasons. Data showed that shoot, root, and sugar yields of sugar beet as well as seed cotton yield were significantly increased with increasing irrigation water level, since the highest values were recorded with $\mathrm{I}_{1}$. Also, the data pointed out that the yields of sugar beet and cotton were significantly increased with organic- $\mathrm{N}$ rate and therefore, $\mathrm{N}_{3}$ treatment gave the highest values. The yields of sugar beet and cotton were significantly increased with increasing K-humate application rate, where, $\mathrm{H}_{2}$ recorded the highest values. Also, the data showed that shoot, root, sugar and cotton yields were significantly increased due to I*N, I* H, N*H and $\mathrm{I}^{*} \mathrm{~N} * \mathrm{H}$ interactions. However, the highest values of shoot, root, sugar and cotton seeds (44.88, 24.05, 9.70 and $2.98 \mathrm{Mg} \mathrm{ha}^{-1}$, respectively) were obtained by $\mathrm{I}_{1} * \mathrm{~N}_{3} * \mathrm{H}_{2}$ interaction. These results are supported by Kiziloglu et al. (2006), Yonts (2011) and Topak et al. (2011). 

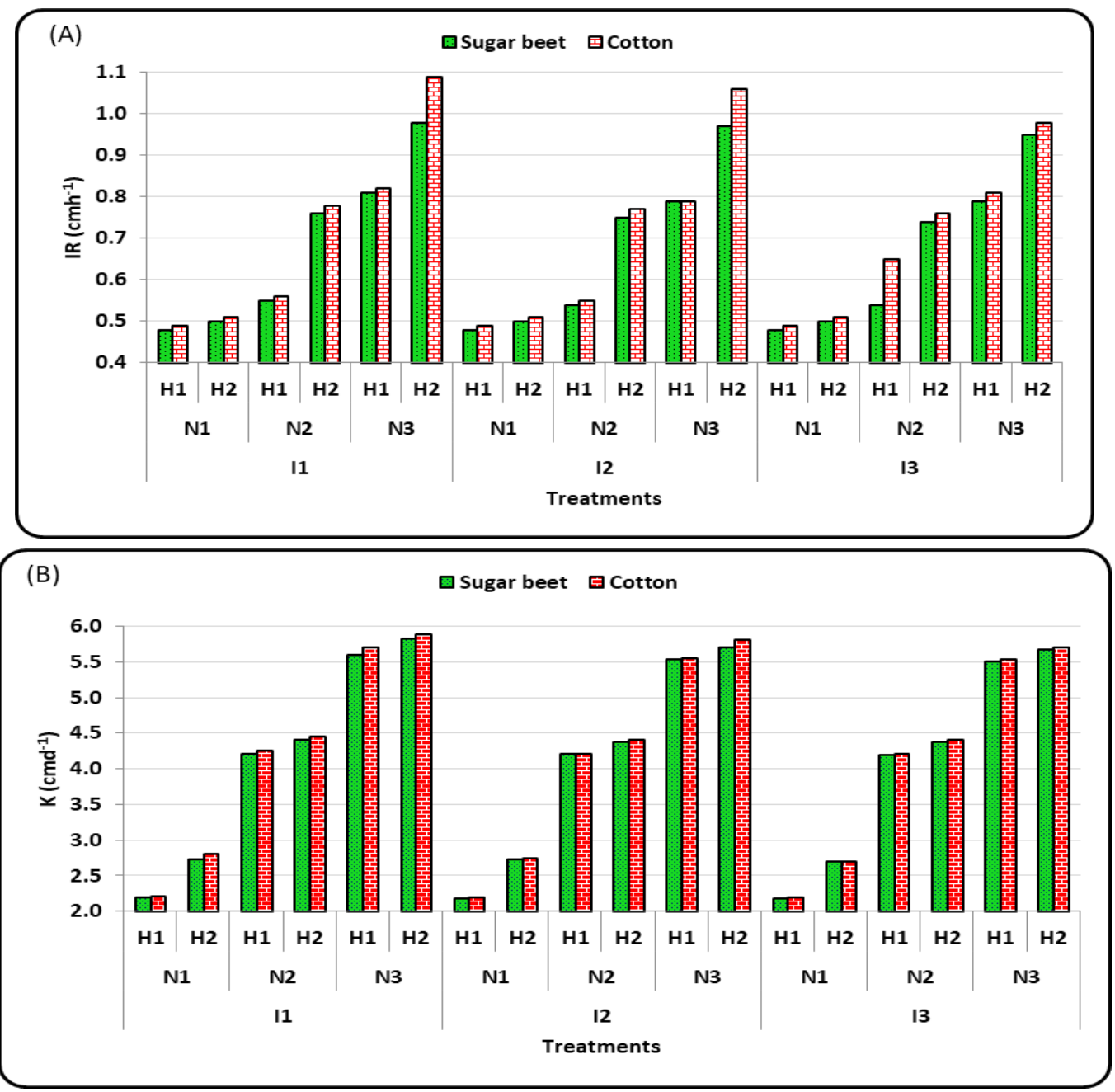

Fig. 2. Infiltration rate, IR $\left(\mathrm{cmh}^{-1}\right)$ and hydraulic conductivity, $K\left(\mathrm{cmd}^{-1}\right)$ as affected by irrigation treatments and organic-chemical fertilizers

TABLE 3. Effect of the treatments and their interaction on productivity of sugar beet and cotton

\begin{tabular}{|c|c|c|c|c|c|}
\hline \multirow{2}{*}{ Treatments* } & \multicolumn{2}{|c|}{ Sugar beet $\left(\mathrm{Mg} \mathrm{ha}^{-1}\right)$} & \multicolumn{3}{|c|}{ Cotton (Mg ha-1) } \\
\hline & Root & Shoot & White sugar & Seed yield & Stalk \\
\hline \multicolumn{6}{|l|}{ Irrigation (I) } \\
\hline $\bar{I}_{1}$ & $42.39 \mathrm{a}$ & $22.56 \mathrm{a}$ & $8.16 \mathrm{a}$ & $3.968 \mathrm{a}$ & $4.666 \mathrm{a}$ \\
\hline $\mathrm{I}_{2}^{1}$ & $37.26 \mathrm{~b}$ & $19.33 b$ & $7.26 \mathrm{~b}$ & $3.776 \mathrm{~b}$ & $4.179 b$ \\
\hline $\mathrm{I}_{3}^{2}$ & $34.63 \mathrm{c}$ & $17.36 \mathrm{c}$ & $\begin{array}{l}7.06 \mathrm{c} \\
* *\end{array}$ & $3.648 \mathrm{c}$ & $4.016 \mathrm{c}$ \\
\hline \multicolumn{6}{|l|}{$\begin{array}{l}\mathrm{r} \text { test } \\
\text { Nitrogen }(\mathrm{N})\end{array}$} \\
\hline $\mathrm{N}$ & $35.76 \mathrm{c}$ & $18.405 \mathrm{c}$ & $6.95 \mathrm{c}$ & $3.657 \mathrm{c}$ & $4.198 \mathrm{c}$ \\
\hline $\mathrm{N}_{2}^{1}$ & $37.67 \mathrm{~b}$ & $19.455 \mathrm{~b}$ & $7.34 \mathrm{~b}$ & $3.769 \mathrm{~b}$ & $4.272 \mathrm{~b}$ \\
\hline $\mathrm{N}_{3}^{2}$ & $40.85 \mathrm{a}$ & $21.388 \mathrm{a}$ & $8.14 a$ & $3.995 \mathrm{a}$ & $4.389 \mathrm{a}$ \\
\hline \multicolumn{6}{|l|}{ Humate potassium $(\mathrm{H})$} \\
\hline$\frac{\text { Humate potassium }(\mathrm{H})}{\mathrm{H}}$ & 37.68 & 19.38 & 7.28 & 3.654 & 4.113 \\
\hline & 38.50 & 20.12 & 7.67 & 3.940 & 4459 \\
\hline $\mathrm{F}_{\text {tets }}^{2}$ & $* *$ & $* *$ & ** & $* *$ & $* *$ \\
\hline \multicolumn{6}{|l|}{$\begin{array}{l}\text { test } \\
\text { Interaction }\end{array}$} \\
\hline & ** & $* *$ & $* *$ & $* *$ & ** \\
\hline $\mathrm{I}^{*} \mathrm{H}$ & $* *$ & $* *$ & ** & $* *$ & $* *$ \\
\hline $\mathrm{N}^{*} \mathrm{H}$ & ** & $* *$ & ** & $* *$ & $* *$ \\
\hline $\mathrm{I}^{*} \mathrm{~N}^{*} \mathrm{H}$ & ** & ** & $* *$ & ** & ** \\
\hline
\end{tabular}

$* \mathrm{I}_{1}, \mathrm{I}_{2}$ and $\mathrm{I}_{3}$ represent 80,100 and $120 \%$ from standard evaporation pan class $\mathrm{A} . \mathrm{N}_{1}: 100 \%$ mineral- $\mathrm{N}, \mathrm{N}_{2}: 80 \%$ mineral-N+ the $20 \%$ compost-N and $\mathrm{N}_{3}: 60 \%$ mineral-N+40\% compost-N, $\mathrm{H}_{1}: 12$ kg K-humate ha ${ }^{-1}$ and $\mathrm{H}_{2}: 24 \mathrm{~kg}$ K-humate ha- ${ }^{-1}$

Env. Biodiv. Soil Security, Vol. 4 (2020) 


\section{Water relations}

Amount of seasonal water applied, WA

The total amounts of WA applied to sugar beet crop including rainfall $(\mathrm{mm})$ and cotton are shown in Fig. 3. It could be noticed that the total amounts of water applied for irrigation treatments were in the following order: $I_{1}>I_{2}>I_{3}$. The values of water applied of sugar beet were 7147.2, 6504.0 and $5901.6 \mathrm{~m}^{3}$ ha $\mathrm{a}^{-1}$ for $\mathrm{I}_{1}, \mathrm{I}_{2}$ and $\mathrm{I}_{3}$, respectively. While the corresponding values for cotton were 10801.2, 9871.2 and $9294.5 \mathrm{~m}^{3} \mathrm{ha}^{-1}$, respectively. These results may be due to the greater number of irrigations under $I_{1}$ than with other treatments. These results are agreed with that obtained by Moursi et al, (2019).

Water consumptive use, WCU

Data in Fig. 3 showed that the mean values of WCU were decreased with $\mathrm{I}_{2}$ and $\mathrm{I}_{3}$ treatments. Therefore, the highest mean values of WCU for sugar beet and cotton (5756.64 and $5973.6 \mathrm{~m}^{3} \mathrm{ha}^{-1}$, respectively) were recorded under $\mathrm{I}_{1}$ treatment. On the other hand, the lowest mean values for sugar beet and cotton (5223.44 and $5803.2 \mathrm{~m}^{3} \mathrm{ha}^{-1}$, respectively) were recorded under $\mathrm{I}_{3}$ treatment. This effect of irrigation treatments on WCU might be attributed to the increase in the amounts of water applied with each irrigation treatment. Finally, seasonal WCU was decreased as soil available water level decreased.
These results are supported with those obtained by Beshara (2012).

Water productivity (WP) and productivity of irrigation water (PIW)

Data in Tables 4 and 5 show the effect of irrigation treatment on WP and PIW for sugar beet and cotton; whereas their mean values were significantly increased under $\mathrm{I}_{2}$ and $\mathrm{I}_{3}$ and consequently recorded the lowest values with $I_{1}$. The increasing of WP and PIW might be due to the decrease in the amount of WCU and WA under the conditions of $\mathrm{I}_{2}$ and $\mathrm{I}_{3}$. Also, the data clear that the values of WP and PIW for root, shoot of sugar beet and both of cotton seed and stalk were significantly increased with the highest rate of organic- $\mathrm{N}\left(\mathrm{N}_{3}\right)$ as compared to $\mathrm{N}_{1}$ and $\mathrm{N}_{2}$. So, the positive effect of organic-N can follow the descending order of: $\mathrm{N}_{3}>\mathrm{N}_{2}>\mathrm{N}_{1}$. Also, application of K-humate had significant positive effect on of WP and PIW for both crops, whereas, the highest values were achieved with $24 \mathrm{~kg} \mathrm{~K}$-humate $\mathrm{ha}^{-1}$. In addition, data in Tables (4 and 5) revealed that WP and PIW values for both crops were significantly affected by I*N, $\mathrm{I}^{*} \mathrm{H}, \mathrm{N}^{*} \mathrm{H}$ and $\mathrm{I}^{*} \mathrm{~N}^{*} \mathrm{H}$ interactions, while the highest values were recorded with $\mathrm{I}_{1} * \mathrm{~N}_{3} * \mathrm{H}_{2}$ interaction. These results are supported with those obtained by Awwad et al. (2015) and Getinet (2016)

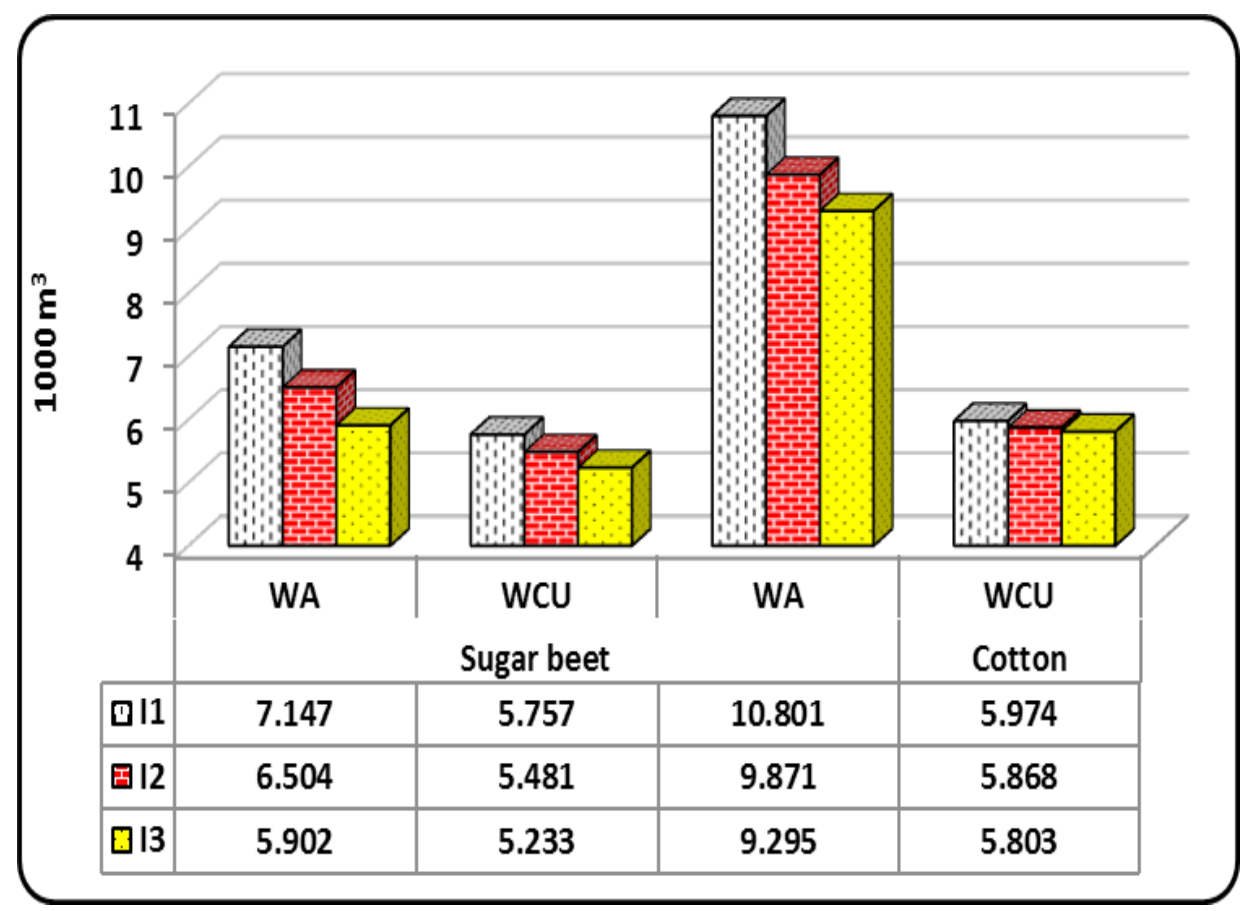

Fig . 3. Water applied and water consumptive use of sugar beet (2018/019) and cotton (2019). 
TABLE 4. Effect of the treatments and their interaction on WP of sugar beet and cotton

\begin{tabular}{|c|c|c|c|c|c|}
\hline \multirow{2}{*}{ Treatments* } & \multicolumn{2}{|c|}{ Sugar beet $\left(\mathrm{kg} \mathrm{m}^{-1}\right)$} & \multicolumn{3}{|c|}{ Cotton $\left(\mathrm{kg} \mathrm{m}^{-1}\right)$} \\
\hline & Root & Shoot & White sugar & Seed yield & Stalk \\
\hline \multicolumn{6}{|l|}{ Irrigation (I) } \\
\hline $\mathrm{I}_{1}$ & $\begin{array}{l}7.36 a \\
670 b\end{array}$ & $3.92 \mathrm{a}$ & $1.42 \mathrm{a}$ & $0.63 \mathrm{~b}$ & $0.77 \mathrm{a}$ \\
\hline $\mathrm{I}^{2}$ & $\begin{array}{l}0.190 \\
661 c\end{array}$ & $\begin{array}{l}5.530 \\
3.32 c\end{array}$ & $\begin{array}{l}1.32 \mathrm{D} \\
1.34 \mathrm{~b}\end{array}$ & $\begin{array}{l}0.040 \\
0.669\end{array}$ & 0.110 \\
\hline $\mathrm{F}_{\text {test }}^{3}$ & $* *$ & $* *$ & $\begin{array}{c}1.340 \\
* *\end{array}$ & $\begin{array}{c}0.06 \mathrm{a} \\
* *\end{array}$ & $0.69 \mathrm{c}$ \\
\hline \multicolumn{6}{|c|}{ Fertilization (N) } \\
\hline $\mathrm{N}$ & $6.49 \mathrm{c}$ & $3.34 \mathrm{c}$ & $1.27 \mathrm{c}$ & $0.62 \mathrm{c}$ & $0.71 \mathrm{c}$ \\
\hline $\mathrm{N}_{2}^{1}$ & $6.85 \mathrm{~b}$ & $3.54 \mathrm{~b}$ & $1.34 \mathrm{~b}$ & $0.64 \mathrm{~b}$ & $0.73 \mathrm{~b}$ \\
\hline $\mathrm{N}_{3}^{2}$ & $7.43 \mathrm{a}$ & $3.89 \mathrm{a}$ & $1.48 \mathrm{a}$ & $0.68 \mathrm{a}$ & $0.75 \mathrm{a}$ \\
\hline $\mathrm{F}_{\text {test }}^{3}$ & ** & ** & ** & ** & ** \\
\hline \multicolumn{6}{|c|}{ Humate potassium(H) } \\
\hline $\begin{array}{l}\mathrm{H}_{1} \\
\mathrm{H}^{2}\end{array}$ & $\begin{array}{l}6.85 \\
700-30\end{array}$ & 3.51 & $\begin{array}{l}1.32 \\
1.40\end{array}$ & 0.62 & 0.69 \\
\hline Ftest & $* *$ & $* *$ & $* *$ & $* *$ & $* *$ \\
\hline \multicolumn{6}{|l|}{ Interaction } \\
\hline I*N & ** & $* *$ & $* *$ & ** & ** \\
\hline $\mathrm{I}^{*} \mathrm{H}$ & $* *$ & $* *$ & $* *$ & ** & ** \\
\hline $\mathrm{N}^{*} \mathrm{H}$ & ** & ** & ** & ** & ** \\
\hline $\mathrm{I} * \mathrm{~N} * \mathrm{H}$ & ** & ** & $* *$ & ** & ** \\
\hline
\end{tabular}

$* \mathrm{I}_{1}, \mathrm{I}_{2}$ and $\mathrm{I}_{3}$ represent 80,100 and $120 \%$ from standard evaporation pan class A. $\mathrm{N}_{1}: 100 \%$ from recommended nitrogen, $\mathrm{N}_{2}: 80 \%$ from recommended nitrogen $+20 \%$ from compost and $\mathrm{N}_{3}: 60 \%$ from recommended nitrogen $+40 \%$ from compost, $\mathrm{H}_{1}$ and $\mathrm{H}_{2}: 12$ and $24 \mathrm{~kg} \mathrm{~K}$-humate ha-1

TABLE 5 Effect of the treatments and their interaction on PIW of sugar beet and cotton

\begin{tabular}{|c|c|c|c|c|c|}
\hline \multirow{2}{*}{ Treatments* } & \multicolumn{2}{|c|}{ Sugar beet $\left(\mathrm{kg} \mathrm{m}^{-1}\right)$} & \multicolumn{3}{|c|}{ Cotton $\left(\mathrm{kg} \mathrm{m}^{-1}\right)$} \\
\hline & Root & Shoot & White sugar & Seed yield & Stalk \\
\hline Irrigation (I) & & & & & \\
\hline $\mathrm{I}_{1}$ & $5.73 \mathrm{c}$ & $3.15 \mathrm{a}$ & $1.14 \mathrm{~b}$ & $0.36 \mathrm{c}$ & 0.43 \\
\hline$I_{2}^{1}$ & $5.87 \mathrm{~b}$ & $2.97 \mathrm{~b}$ & $1.12 \mathrm{~b}$ & $0.38 \mathrm{~b}$ & 0.43 \\
\hline $\mathrm{I}_{3}^{2}$ & $5.93 \mathrm{a}$ & $2.94 b$ & $1.19 \mathrm{a}$ & $0.40 \mathrm{a}$ & 0.43 \\
\hline $\mathrm{F}_{\text {test }}^{3}$ & $* *$ & $* *$ & $* *$ & $* *$ & ns \\
\hline \multicolumn{6}{|l|}{ Fertilization $(\mathrm{N})$} \\
\hline $\mathrm{N}_{1}$ & $5.47 \mathrm{c}$ & $2.81 \mathrm{c}$ & $1.06 \mathrm{c}$ & $0.36 \mathrm{c}$ & $0.42 \mathrm{c}$ \\
\hline $\mathrm{N}_{2}^{1}$ & $5.77 \mathrm{~b}$ & $2.97 \mathrm{~b}$ & $1.13 b$ & $0.38 \mathrm{~b}$ & $0.43 \mathrm{~b}$ \\
\hline $\mathrm{N}_{3}^{2}$ & $6.28 \mathrm{a}$ & $3.28 \mathrm{a}$ & $1.26 \mathrm{a}$ & $0.40 \mathrm{a}$ & $0.44 \mathrm{a}$ \\
\hline $\mathrm{F}_{\text {test }}^{3}$ & $* *$ & $* *$ & $* *$ & $* *$ & $* *$ \\
\hline \multicolumn{6}{|l|}{ Humate potassium $(\mathrm{H})$} \\
\hline - & 5.78 & 2.96 & 1.13 & 0.36 & 0.41 \\
\hline $\mathrm{H}_{2}^{1}$ & 5.91 & 3.08 & 1.18 & 0.40 & 0.45 \\
\hline $\mathrm{F}_{\text {test }}^{2}$ & $* *$ & $* *$ & $* *$ & $* *$ & $* *$ \\
\hline \multicolumn{6}{|l|}{ Interaction } \\
\hline$I^{*} \mathrm{~N}$ & $* *$ & ** & ** & ** & ** \\
\hline $\mathrm{I}^{*} \mathrm{H}$ & ** & ** & $* *$ & ** & ** \\
\hline $\mathrm{N}^{*} \mathrm{H}$ & ** & $* *$ & $* *$ & ** & ** \\
\hline $\mathrm{I} * \mathrm{~N} * \mathrm{H}$ & $* *$ & $* *$ & ** & $* *$ & ** \\
\hline
\end{tabular}

$* \mathrm{I}_{1}, \mathrm{I}_{2}$ and $\mathrm{I}_{3}$ represent 80,100 and $120 \%$ from standard evaporation pan class A. $\mathrm{N}_{1}: 100 \%$ from recommended nitrogen, $\mathrm{N}_{2}: 80 \%$ from recommended nitrogen $+20 \%$ from compost and $\mathrm{N}_{3}: 60 \%$ from recommended nitrogen $+40 \%$ from compost, $\mathrm{H}_{1}$ and $\mathrm{H}_{2}: 12$ and $24 \mathrm{~kg} \mathrm{ha}^{-1} \mathrm{~K}$-humate

\section{Economical evaluation}

Data in Table 6 showed the costs of the agricultural practices for sugar beet and cotton $\left(\mathrm{LE} \mathrm{ha}^{-1}\right.$ ). Data in Fig. (4.a and b) showed that total income and net return for sugar beet and cotton were showed the highest values with irrigation at $80 \%$ from standard evaporation pan class $\mathrm{A}$ $\left(I_{1}\right)$. The effect of irrigation treatments on the total income and net return values for both crops can be arranged in the following order: $\mathrm{I}_{1}>\mathrm{I}_{2}>\mathrm{I}_{3}$.
Also, the application of organic-N had positive effect on increasing of total income and net return for both crops and the highest values of both parameters were recorded with $\mathrm{N}_{3}$. Consequently, the total income and net return values for both crops as affected by $\mathrm{N}$-organic are decreased in the following order: $\mathrm{N}_{3}>\mathrm{N}_{2}>\mathrm{N}_{1}$. With regarded to application of K-hummate, total income and net return for both crops showed higher values with $\mathrm{H}_{2}$ treatment. Also, the results showed that the

Env. Biodiv. Soil Security, Vol. 4 (2020) 
highest values of both parameters for both crops were achieved due to $\mathrm{I}_{1} * \mathrm{~N}_{3} * \mathrm{H}_{2}$ interaction. Also, the benfit costs ratio took the same trend, whereas the highest values for sugar beet and cotton (1.70 and 1.94 , respectively) were recorded with $\mathrm{I}_{1} * \mathrm{~N}_{3} * \mathrm{H}_{2}$ as show in (Fig.4-c). In addition, the highest net return from water unit, IWU for sugar beet $\left(2.17 \mathrm{LEm}^{-3}\right)$ was obtained by $\mathrm{I}_{1}^{*} \mathrm{~N}_{3} * \mathrm{H}_{1}$, while the highest value for cotton (2.55 $\left.\mathrm{LEm}^{-3}\right)$ was achieved with $\mathrm{I}_{2} * \mathrm{~N}_{3} * \mathrm{H}_{2}$ as show in (Fig.4-d).

\section{Conclusion}

It could be concluded that irrigation at $80 \%$ from standard evaporation pan class A, application of organic-N $(40 \%)$ and mineral-N $(60 \%)$ from the recommended $\mathrm{N}$ with $24 \mathrm{~kg}$ K-hummat ha $^{-1}\left(\mathrm{I}_{1} * \mathrm{~N}_{3} * \mathrm{H}_{2}\right)$ was more effective treatment in improving some soil properties such as cation exchange capacity, soil organic matter, infiltration rate, hydraulic conductivity and water productivity as well as yield of sugar beet and cotton in salt affected soils.

TABLE 6. Agricultural operations costs for sugar beet and cotton production (LE ha-1)

\begin{tabular}{|c|c|c|c|c|c|c|c|c|}
\hline \multirow{2}{*}{\multicolumn{3}{|c|}{ Treatments }} & \multirow{3}{*}{ Fixed $\operatorname{cost}(a)^{*}$} & \multicolumn{4}{|c|}{ Variable cost (b) } & \multirow{3}{*}{$\begin{array}{l}\text { Total cos } \\
\quad(\mathbf{a}+\mathbf{b})\end{array}$} \\
\hline & & & & \multirow{2}{*}{$\begin{array}{l}\text { N-mineral } \\
\text { Sugar beet }\end{array}$} & \multirow{2}{*}{ N-organic } & \multirow[t]{2}{*}{ H-K } & \multirow{2}{*}{ total } & \\
\hline & & & & & & & & \\
\hline \multirow{6}{*}{ I1 } & \multirow{2}{*}{ N1 } & H1 & 19440 & 1651 & 0 & 0 & 1651.0 & 21091.0 \\
\hline & & $\mathrm{H} 2$ & 19440 & 1651 & 0 & 240 & 1891.0 & 21331.0 \\
\hline & \multirow{2}{*}{$\mathrm{N} 2$} & $\mathrm{H} 1$ & 19440 & 1320.8 & 910 & 0 & 2230.8 & 21670.8 \\
\hline & & $\mathrm{H} 2$ & 19440 & 1320.8 & 910 & 240 & 2470.8 & 21910.8 \\
\hline & \multirow{2}{*}{ N3 } & $\mathrm{H} 1$ & 19440 & 990.6 & 1820 & 0 & 2810.6 & 22250.6 \\
\hline & & $\mathrm{H} 2$ & 19440 & 990.6 & 1820 & 240 & 3050.6 & 22490.6 \\
\hline \multirow{6}{*}{$\mathrm{I} 2$} & \multirow{2}{*}{ N1 } & H1 & 19440 & 1651 & 0 & 0 & 1651.0 & 21091.0 \\
\hline & & $\mathrm{H} 2$ & 19440 & 1651 & 0 & 240 & 1891.0 & 21331.0 \\
\hline & \multirow{2}{*}{$\mathrm{N} 2$} & $\mathrm{H} 1$ & 19440 & 1320.8 & 910 & 0 & 2230.8 & 21670.8 \\
\hline & & $\mathrm{H} 2$ & 19440 & 1320.8 & 910 & 240 & 2470.8 & 21910.8 \\
\hline & \multirow{2}{*}{ N3 } & $\mathrm{H} 1$ & 19440 & 990.6 & 1820 & 0 & 2810.6 & 22250.6 \\
\hline & & $\mathrm{H} 2$ & 19440 & 990.6 & 1820 & 240 & 3050.6 & 22490.6 \\
\hline \multirow{6}{*}{ I3 } & \multirow{2}{*}{ N1 } & $\mathrm{H} 1$ & 19440 & 1651 & 0 & 0 & 1651.0 & 21091.0 \\
\hline & & $\mathrm{H} 2$ & 19440 & 1651 & 0 & 240 & 1891.0 & 21331.0 \\
\hline & \multirow{2}{*}{$\mathrm{N} 2$} & H1 & 19440 & 1320.8 & 910 & 0 & 2230.8 & 21670.8 \\
\hline & & $\mathrm{H} 2$ & 19440 & 1320.8 & 910 & 240 & 2470.8 & 21910.8 \\
\hline & \multirow{2}{*}{ N3 } & $\mathrm{H} 1$ & 19440 & 990.6 & 1820 & 0 & 2810.6 & 22250.6 \\
\hline & & $\mathrm{H} 2$ & 19440 & 990.6 & 1820 & 240 & 3050.6 & 22490.6 \\
\hline & & & & Cotton & & & & \\
\hline \multirow{6}{*}{ I1 } & \multirow{2}{*}{ N1 } & H1 & 25512 & 1611.9 & 0 & 0 & 1611.9 & 27123.9 \\
\hline & & $\mathrm{H} 2$ & 25512 & 1611.9 & 0 & 240 & 1851.9 & 27363.9 \\
\hline & \multirow{2}{*}{$\mathrm{N} 2$} & $\mathrm{H} 1$ & 25512 & 1298.5 & 980 & 0 & 2278.5 & 27790.5 \\
\hline & & $\mathrm{H} 2$ & 25512 & 1298.5 & 980 & 240 & 2518.5 & 28030.5 \\
\hline & \multirow{2}{*}{ N3 } & $\mathrm{H} 1$ & 25512 & 967.1 & 1925 & 0 & 2892.1 & 28404.1 \\
\hline & & $\mathrm{H} 2$ & 25512 & 967.1 & 1925 & 240 & 3132.1 & 28644.1 \\
\hline \multirow{6}{*}{$\mathrm{I} 2$} & & $\mathrm{H} 1$ & 25512 & 1611.9 & 0 & 0 & 1611.9 & 27123.9 \\
\hline & N1 & $\mathrm{H} 2$ & 25512 & 1611.9 & 0 & 240 & 1851.9 & 27363.9 \\
\hline & & $\mathrm{H} 1$ & 25512 & 1298.5 & 980 & 0 & 2278.5 & 27790.5 \\
\hline & N2 & $\mathrm{H} 2$ & 25512 & 1298.5 & 980 & 240 & 2518.5 & 28030.5 \\
\hline & & $\mathrm{H} 1$ & 25512 & 967.1 & 1925 & 0 & 2892.1 & 28404.1 \\
\hline & N3 & $\mathrm{H} 2$ & 25512 & 967.1 & 1925 & 240 & 3132.1 & 28644.1 \\
\hline & & $\mathrm{H} 1$ & 25512 & 1611.9 & 0 & 0 & 1611.9 & 27123.9 \\
\hline & N1 & $\mathrm{H} 2$ & 25512 & 1611.9 & 0 & 240 & 1851.9 & 27363.9 \\
\hline & & $\mathrm{H} 1$ & 25512 & 1298.5 & 980 & 0 & 2278.5 & 27790.5 \\
\hline $\mathrm{I} 3$ & $\mathrm{~N} 2$ & $\mathrm{H} 2$ & 25512 & 1298.5 & 980 & 240 & 2518.5 & 28030.5 \\
\hline & & $\mathrm{H} 1$ & 25512 & 967.1 & 1925 & 0 & 2892.14 & 28404.1 \\
\hline & N3 & $\mathrm{H} 2$ & 25512 & 967.1 & 1925 & 240 & 3132.1 & 28644.1 \\
\hline
\end{tabular}

*Fixed cost (a) including soil rent, cost of tillage, irrigation, seed, planting, workers, fertilizer and harvesting. Treatments $\mathrm{I}_{1}$, $\mathrm{I}_{2}$ and $\mathrm{I}_{3}$ represent 80,100 and $120 \%$ from standard evaporation pan class A. $\mathrm{N}_{1}: 100 \%$ from recommended nitrogen, $\mathrm{N}_{2}: 80 \%$ from recommended nitrogen $+20 \%$ from compost and $\mathrm{N}_{3}: 60 \%$ from recommended nitrogen $+40 \%$ from compost, $\mathrm{H}_{1}$ and $\mathrm{H}_{2}: 12$ and $24 \mathrm{~kg} \mathrm{~K}$-humate ha-1 

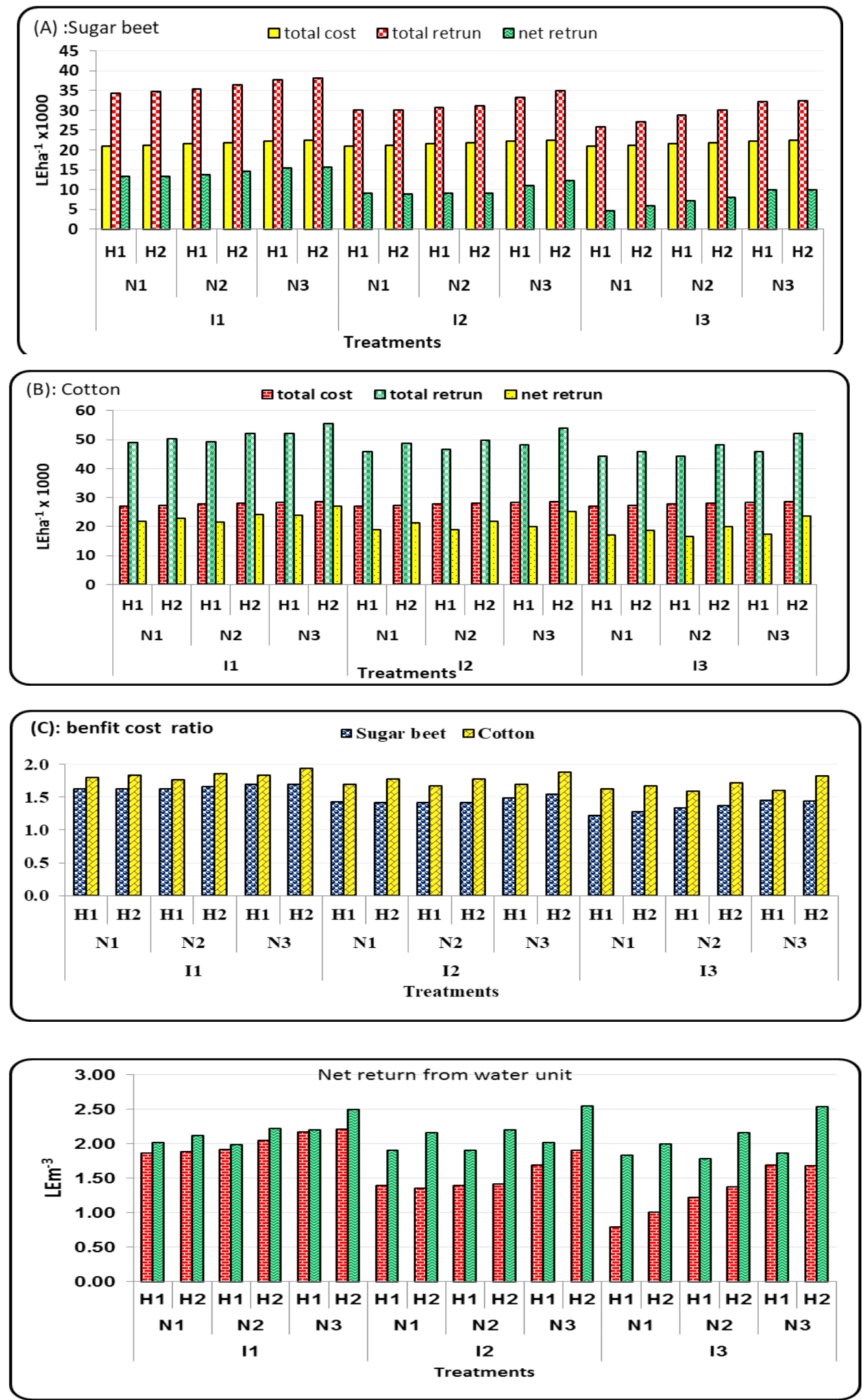

Fig. 4. Total cost, total retrun and net retrun for production both of sugar beet $(\mathrm{A})$, cotton $(\mathrm{B})$, benfit costs ratio (c) and net retrun from water unit (D) 


\section{References}

Aiad M. A. (2019) Productivity of Heavy Clay Soils as Affected by Some Soil Amendments Combined with Irrigation Regime. Env. Biodiv. Soil Security, $3,147-162$

Alaoui, A., Rogger, M., Peth, S. and G. Blöschl, (2018) Does soil compaction increase floods? A review, $J$. of Hydrology, 557, 631-642.

Ali, M. H., Hoque, M. R., Hassan, A. A. and A. Khair (2007) Effect of deficit irrigation on yield water productivity and economic returns of wheat. Agric. Water Management, 92 (3): 151-161.

Amer M, Aiad M. , Rashed S. and H. El-Ramady (2019) Sustainable Irrigation and Fertilization Management of Successive Cultivated Sugar Beet and Cotton under Salt-affected Soil Conditions. Env. Biodiv. Soil Security, 3, 227 - 239

Amer M, H.M. Aboelsoud, E.H.Omar and M.G. Zoghdan (2018). Assessing The Impact of Shallow Groundwater on Soil Salinity and Biomass Yield of Plants Grown in North Nile Delta Using Remote Sensing and GIS. Egypt. J. Soil. Sci. 58 (1):57-71.

Awwad, M.S.; K.S. El-Hedek, M.A. Bayoumi and T.A. Eid (2015) Effect of Potassium Humate Appliction And Irrigation Water Levels on Maize Yield, Crop Water Productivity And Some Soil Properties. J. Soil Sci. and Agric. Eng., Mansoura Univ., 6 (4): $461-482$.

Ayars, J.E., Hutmacher, R.B., Schoneman, R.A., Vale, S.S., and T. Pllaum (1993) Long term use of saline water for irrigation. Irrig. Sci. 14, 27-34.

Beshara, A.T. (2012) Effect of soil moisture depletion and nitrogen fertilizer application date on wheat yields, water and fertilizer use efficiencies in North Africa. Ph.D. Thesis, Institute of African Research and Studies. Cairo Univ.

Brater, E.F. and H.W. King (1976) Handbook of Hydraulics. McGeavy, Hill Book Company, 61 ed, NY

Chaney, K. and R .S. Swift (1986) Studies on aggregate stability. I. Re-formation of soil aggregates. J. of Soil Sci. 37: 329-335

Churchman, G. J. (2018) Game changer in soil science: Functional role of clay minerals in soil. J. Plant Nutr. Soil Sci.181, 99-103

Duncan, B. D. (1955) Multiple range and multiple F-test. - Bionetrics, 11, 1-42
Elbasiouny, H.; F. Elbehiry and M. Abowaly (2017) Soil Quality Indices- Special Focus on SaltAffected Soil: Review and Case Study in Northern Egypt. Env. Biodiv. Soil Security, Vol.1, pp.85- 100.

English, M. and S.N. Raja, (1996). Perspectives on deficit irrigation. Agric. Water Management, 32 (1): $1-14$

Garcia, G. (1978) Soil water Engineering Laboratory Manual. Colorado State Univ. Dept. of Agric. and Chemical Engineering. Fort Collins, Colorado.

Getinet, A. (2016).A review on impact of compost on soil properties, water use and crop productivity, Agric.Sci.Res.J. 4 (3):93-104

Gittinger, J. P. (1982) Economic Analysis of Agric. Projects, Second edition, Completely Revised and Expanded, the Johns Hopkins University Press BALTIMORE AND LONDON

Gomez, K.A.and A.A. Gomez (1984) Statistical Procedures for Agric. Res., $2^{\text {nd }}$ edition.

Hansen, V. W.; O. W. Israelson and Q. E. Stringham (1979) "Irrigation Principles and Practices". 4th ed., John willey and Sons. New York

Horneck, D.A., Ellsworth, J.W.; Hopkins, B.G.; Sullivan, D.M. and R.G. Stevens (2007) Managing Salt-affected Soils for Crop Production. A Pacific Northwest Extension publication, Oregon State Univ.

Ibrahim, M. A. A.1 and A. M. Abd El-Hafeez (2017) Impact of Integrated Mineral and Organic Fertilization and Foliar Spraying of some Micronutrints on Cotton Productivity. J. Soil Sci. and Agric. Eng., Mansoura Univ., 8 (12): 829-835

Khambalkar, M. S.; V. V. GAbhane and S. V. Khambalkar (2017) Studies on effect of integrated nutrient management on productivity of cotton in rainfed condition. Int. J. Curr. Microbiol. App. Sci. 6 (8) 3639-3641

Kiziloglu, F.M.,U.Sahin, I. Angin and O. Anapali (2006) The effect of deficit irrigation on water-yield relationship of sugar beet (Beta vulgaris L.) under cool season and semi -arid climatic conditions. International sugar J. 108 (1286):90:94

Ladislav M.,L. Hlisnikovský, L. Pospíšilová and E. Kunzová (2018) The effect of application of organic manures and mineral fertilizers on the state of soil organic matter and nutrients in the longterm field experiment. $J$. of Soils and Sediments 18:2813-2822

Env. Biodiv. Soil Security, Vol. 4 (2020) 
Lugato E, Panagos P, Bampa F et al. (2014) A new baseline of organic carbon stock in European agric. soils using a modelling approach. Glob Chang Biol. 20:313-326

Masoud, F.I. (1969) Principles of Agricultural Irrigation. Dar ELmatbouat Elgadidah, Alexandria (in Arabic).

Meleha, M. E. (2000) Effect of furrow length and methods of applying irrigation water on cotton yield and water use efficiency. J. Agric. Sci. Mansoura Univ. 25: 3883-3890

Moursi E., R. M. Khalifa, A. M. Meleha, and M. A. Aiad (2019) Effect of Irrigation Scheduling at Different Management Allowable Deficit Using Pan Evaporation on Wheat Yield and Water efficiencies at North Delta, J. Sus. Agric. Sci. 45 (1): 11-25

Novica, V. (1979) Irrigation of agric. crops. Fac. Agric. Press, Novi Sad, Yogoslavia.

Page, A. L.; R. H. Miller and D. R. Keeny (1982) Methods of Soil Analysis. $2^{\text {nd }}$ edition part 2 :Chemical and Microbiological Properties. American Society of Agronomy, Madisons, Wisconsin, USA

Plaza-Bonilla D, J.L. Arrúe, C. Cantero-Martínez, R. Fanlo, A. Iglesias and J. Álvaro-Fuentes (2015) Carbon management in dry land agricultural systems. A review. Agron. Sustain Dev. 35(4):1319-1334

Richard G. A. , L. S. Pereira, D. Raes and M. Smith (1977) Crop Evapotranspiration (guidelines for computing crop water requirements) FAO Irrigation and Drainage Paper No.56 FAO, Water Resources, Development and Management Service Rome, Italy
Richards, L. A. (1954) "Diagnosis and Improving of Saline and Alkaline Soils". U. S., Salinity Laboratory Staff. Agric. Handbook, No.60.

Sarkar, B., Singh, M., Mandal, S., Churchman, G.J. and N.S. Bolan (2018) Chapter 3 - Clay MineralsOrganic Matter Interactions in Relation to Carbon Stabilization in Soils, Ed.: Carlos Garcia, Paolo Nannipieri, Teresa Hernandez, The Future of Soil Carbon, Academic Press, pp. 71-86

Topak, R., S. Süheri, and B. Acar. (2011) Effect of different drip irrigation regimes on sugar beet (Beta vulgaris $L$.) yield, quality and water use efficiency in Middle Anatolian, Turkey. Irrigation Science 29:79-89.

Van Beers, W.F.J. (1958) The Auger-Hole method, Bulletin 1, Int. Inst. for land recl. and impor, Wageningen, The Netherland.

Wailare, A. T. and A. Kesarwani (2017) Effect of integrated nutrient management on growth and yield parameters of maize (Zea mays L.) as well as soil physicochemical properties.

Yang R, Su Y.Z, T. Wang and Q. Yang (2016) Effect of chemical and organic fertilization on soil carbon and nitrogen accumulation in a newly cultivated farmland. J Integr. Agric. 15 (3):658-666

Yonts, D.C. (2011) Development of season long deficit irrigation strategies for sugar beets. ASSBT Annual Meeting Proceedings, http://assbt-proceedings.org/ ASSBT2011Proceedings/Agronomy/Yonts.pdf (Accessed 20 September 2017). 